\title{
An approach to diagnosis and management of acute fatty liver of pregnancy
}

\author{
Neha Gami*, Seema Singhal, Manju Puri, Amita Dhakad
}

Department of Obstetrics \& Gynecology, Lady Hardinge Medical College, New Delhi-110001, India

Received: 9 January 2013

Accepted: 19 January 2013

\author{
*Correspondence: \\ Dr. Neha Gami \\ E-mail: nehagami@hotmail.com
}

\begin{abstract}
Acute fatty liver of pregnancy is a rare life threatening cause of jaundice in the third trimester of pregnancy and early postpartum period and is associated with a poor outcome. The maternal and fetal outcome can be improved by a high index of suspicion, early diagnosis and prompt delivery. We report a case of a 30 year old parous lady with 36 weeks twin pregnancy with Acute Fatty Liver of Pregnancy [AFLP] and coagulation failure, she responded to prompt induction of labour and appropriate management of the coagulopathy and related complications. We provide a review of literature on jaundice in pregnancy and the clinical approach to management.
\end{abstract}

Keywords: AFLP, Pregnancy, Jaundice

\section{INTRODUCTION}

Management of jaundice during pregnancy especially in third trimester remains a dilemma for the obstetrician because of its varied aetiology, unpredictable prognosis and guarded perinatal outcome. Diagnosing the aetiology of jaundice is extremely important in pregnant patients as certain conditions like Acute fatty liver of pregnancy (AFLP), HELLP syndrome and intra-hepatic cholestasis of pregnancy (ICP) may require early termination of pregnancy even in the presence of jaundice and or coagulation failure. ${ }^{1}$ On the other hand, in conditions like acute viral hepatitis one must try to prolong pregnancy till the liver has recovered. Thus, the maternal and fetal outcomes of pregnancy can significantly be improved by appropriate management. Acute fatty liver of pregnancy is a rare but life threatening cause of jaundice in the third trimester of pregnancy and early postpartum period. It is associated a high maternal and neonatal mortality. ${ }^{2,3}$ Once diagnosed, prompt delivery is associated with a significantly improved outcome but peripartum management becomes difficult if the pregnancy is complicated by coagulation failure also.

We report a case of a 30 year old parous lady with 36 weeks gestation with twin pregnancy who was diagnosed to have Acute Fatty Liver of Pregnancy [AFLP] with coagulation failure. She responded to prompt delivery and appropriate management of the coagulopathy.

\section{CASE REPORT}

A 30 year old lady, G4P2L2A1, 36 weeks pregnant with twin pregnancy was admitted to the hospital with a history of yellow discolouration of urine and eyes, malaise, anorexia and loose stools for 6 days. There was a history of increased sleepiness for 2 days. She had no complaints of pain abdomen, bleeding or leaking per vaginum, or decreased fetal movements. She was referred from a peripheral hospital in view of prematurity, twin pregnancy and jaundice.

On examination, the patient was conscious, oriented and responding appropriately to verbal commands. Her hydration was fair, temperature was 37 degree celsius, pulse rate was $88 / \mathrm{min}$, BP $130 / 80 \mathrm{~mm} \mathrm{Hg}$ in right arm supine position, and the respiratory rate was $20 / \mathrm{min}$. She had icterus, mild pallor and pedal edema. On abdominal examination, the uterus was found to be over-distended with multiple fetal parts. Both twins were alive and uterus was relaxed. The investigations revealed a hemoglobin of $9.1 \mathrm{gm} / \mathrm{dl}$, white blood cell count $9,900 / \mathrm{mm}^{3}$, platelet 
count of 1.5 lacs/cubic mm, peripheral smear showed a microcytic hypochromic anemia. Her liver function tests showed a serum bilirubin of $13.9 \mathrm{mg} / \mathrm{dl}$, alanine aminotransferase 390U/1, aspartate aminotransferase 368 $\mathrm{U} / 1$, alkaline phosphatase $561 \mathrm{u} / \mathrm{l}$, total protein $5.6 \mathrm{gm} / \mathrm{dl}$, and albumin $2.4 \mathrm{gm} / \mathrm{dl}$. Kidney function tests revealed blood urea $64 \mathrm{mg} / \mathrm{dl}$ and creatinine $1.1 \mathrm{mg} / \mathrm{dl}$. Random blood sugar was $87 \mathrm{mg} / \mathrm{dl}$. The coagulation profile showed a prothrombin time $25.4 \mathrm{sec}$ (control $12 \mathrm{sec}$.), with INR of 2.12 and a partial thromboplastin time of $>180$ seconds (control 29 sec.). Urine analysis showed mild proteinuria (1+) with $18-20$ pus cells and positive leukocyte esterase. Ultrasound of the abdomen showed a normal liver, gall bladder, and biliary system. A differential diagnosis of AFLP, HELLP syndrome, or acute viral hepatitis was made. In addition, she had urinary tract infection. The patient was started on intravenous antibiotics, syrup lactulose and high carbohydrate diet to avoid hepatic failure and sepsis. However, the patient's sensorium worsened, her bilirubin rose to $25 \mathrm{mg} / \mathrm{dl}$ and the platelet count fell to $41,000 / \mathrm{mm}^{3}$. She developed grade I hepatic encephalopathy and had intrauterine demise of both the twins. A diagnosis of Acute Fatty Liver of Pregnancy was entertained as her viral serology turned out to be negative for hepatitis A, B, and E. A decision was taken to induce labour after correction of the coagulation profile by transfusing 4 units of fresh frozen plasma (FFP) followed by 2 units 8 hourly. The patient was induced with tablet misoprostol 25 microgram (3 doses at hour intervals) followed by oxytocin augmentation. She received 12 units of FFP prior to delivery. Following the delivery, the patient had atonic postpartum haemorrhage. Uterine massage was started, the genital tract was explored and a few lacerations were seen in vagina which were stitched. The cervix was found to be intact. Oxytocin drip (20 units in $500 \mathrm{ml} \mathrm{NS}$ ) was started and 1000 microgram misoprostol was inserted per rectally. The patient continued to have atonic PPH inspite of massage. Since the bleeding did not reduce by medical management alone, balloon tamponade was done. Oxytocin was continued 24 hours post-delivery. The balloon was deflated and removed after further transfusion of FFP and platelets at about 32 hours post-delivery.

Her serum bilirubin remained elevated ( $>25 \mathrm{mg} / \mathrm{dl})$ until 5 days after delivery although enzymes rapidly improved. Postpartum USG showed an enlarged liver with ascites. The patient was started on diuretics with reduction of ascites. She was discharged on day 13 after delivery with consistent improvement in liver function tests.

\section{DISCUSSION}

The causes of jaundice in pregnancy can be classified as those which are peculiar to pregnancy and those which are coincidental with pregnancy. Hyperemesis gravidarum, cholestasis of pregnancy, preeclampsia with HELLP syndrome and AFLP are peculiar to pregnancy while viral and drug induced hepatitis may occur concurrently with pregnancy (Tables $1,2,3$ ).

Acute fatty liver of pregnancy is a rare condition that affects pregnant women usually in the third trimester of pregnancy. It is associated with a very high maternal and perinatal mortality. It is essential to diagnose this condition as prompt delivery can help to reduce the maternal and perinatal mortality.

Long chain 3-hydroxyacyl CoA dehydrogenase (LCHAD) is an enzyme which is a part of the enzyme complex known as the mitochondrial trifunctional protein (MTP). It is believed that G1528C and E474Q mutations of MTP gene lead to LCHAD deficiency. When a woman heterozygous for these mutations has a fetus homozygous for this defect, it results in accumulation of fetal fatty acids which return to the mother's circulation. This extra load of long chain fatty acids and hence triglycerides lead to fat deposition in the hepatocytes and impaired liver functions resulting in acute fatty liver of pregnancy.

Once the diagnosis of AFLP is made, the definitive management is early delivery of the fetus. However, the crucial decision of timing of delivery is made even more difficult by the presence of derangement in the coagulation profile. It has been seen that such patients respond well to induction of labour and it is not essential to perform a caesarian section. In fact, at our center we try and avoid surgical intervention in the presence of coagulation failure. At the same time, we must attempt to correct the derangement by adequate replacement of blood and its components. In the present case, transfusion of FFPs till the prolongation in INR was corrected and the use of balloon tamponade to manage atonic PPH helped the most in managing the patient. In the presence of coagulation failure, there is a higher chance of PPH and a decision to do a laparotomy for step wise devascularisation may not be safe for the patient. In such a situation, internal compression by balloon tamponade using a Foley's catheter and condom is quite effective in controlling the hemorrhage. ${ }^{12,13}$

After delivery, the patients usually improve in 24-48 hours but it may take many days before the liver functions return to normal.

Sometimes the liver function may even deteriorate till about 1 week postpartum and then recover slowly. Hence, these patients must stay under close monitoring till the improvement starts and is consistent.

Theoretically, the risk of recurrence in subsequent pregnancies is about $25 \%$ (fetus is homozygous or compound heterozygous for LCHAD deficiency) but practically very few cases of recurrence have been reported. However, all women must be counseled regarding the risk in future pregnancies and should be tested for LCHAD deficiency. 
Table 1: Classification of liver diseases peculiar to pregnancy.

\begin{tabular}{|c|c|c|c|}
\hline Cause & Trimester & Incidence & Symptoms \& Signs \\
\hline $\begin{array}{l}\text { Hyperemesis } \\
\text { gravidarum }\end{array}$ & $1^{\text {st }} \mathrm{T}-$ early $2^{\text {nd }} \mathrm{T} *$ & $0.3 \%-2 \%^{4}$ & $\begin{array}{l}\text { Intractable nausea } \\
\text { vomiting } \\
\text { weight loss }>=5 \%\end{array}$ \\
\hline $\begin{array}{l}\text { Preeclampsia or } \\
\text { eclampsia }\end{array}$ & $\begin{array}{l}\text { Late } 2^{\text {nd }} \text { or } 3^{\text {rd }} \mathrm{T} / \text { early } \\
\text { postpartum }\end{array}$ & $5-10 \%$ & $\begin{array}{l}\text { Edema } \\
\text { Hypertension } \\
\text { Nausea } \\
\text { Vomiting } \\
\text { Blurring of vision } \\
\text { Epigastric pain } \\
\text { Jaundice }\end{array}$ \\
\hline $\begin{array}{l}\text { HELLP } \\
\text { hemolysis, } \\
\text { elevated liver } \\
\text { enzymes and } \\
\text { low platelet } \\
\text { count. }\end{array}$ & $70 \%-3^{\text {rd }} T^{6}$ & $0.1 \% * *$ & $\begin{array}{l}\text {-Right upper } \\
\text { abdominal pain } \\
\text {-nausea } \\
\text {-vomiting } \\
\text {-malaise } \\
\text {-edema } \\
\text {-significant weight gain } \\
\text {-hypertension (may be absent in } 20 \% \text { ) } \\
\text {-proteinuria }\end{array}$ \\
\hline AFLP & $3^{\mathrm{rd}} \mathrm{T}$ & $0.01 \%^{7}$ & $\begin{array}{l}1-2 \text { wk history of nausea } \\
\text { - vomiting } \\
\text {-abdominal pain } \\
\text { fatigue } \\
\text { jaundice (v. common) } \\
\text { hypoglycemia } \\
\text { hepatic encephalopathy (late) } \\
\text { coagulopathy } \\
50 \% \text { s/s of preeclampsia }\end{array}$ \\
\hline $\begin{array}{l}\text { Intra hepatic } \\
\text { cholestasis of } \\
\text { pregnancy }\end{array}$ & Late $2^{\text {nd }}$ or $3^{\text {rd }}$ trimester & $\begin{array}{l}\text { (iii) } 1 / 1000- \\
1 / 10,000 \text { (increase } \\
\text { prevalence in } \\
\text { increase maternal } \\
\text { age, multiparous, } \\
\text { personal history of } \\
\text { cholestasis) } 0.1 \%- \\
0.2 \%^{7}\end{array}$ & $\begin{array}{l}\text { Pruritus (starts with palm and soles \& } \\
\text { progresses to rest of body, worse at night) } \\
\text { Jaundice in } 10-25 \% \text { [20-60\% }^{7} \text { (1-4 wks } \\
\text { after pruritus), increased incidence of } \\
\text { choleslithiasis and cholecystitis. } \\
\text { Fatigue, \& anorexia, } \\
\text { epigastric pain, } \\
\text { steatorrhea. }\end{array}$ \\
\hline
\end{tabular}

* $10 \%$ - throughout pregnancy

$* * 4-12 \%$ of women with preeclampsia

Table 2: Biochemical derangements in different pregnancy related liver disorders.

\begin{tabular}{|lllllll|}
\hline Investigations & AFLP & $\begin{array}{c}\text { Hyper- } \\
\text { emesis }\end{array}$ & Pre-eclampsia & ICP & HELLP & Hepatitis \\
\hline S. Bil & $\uparrow \uparrow$ & Mild $\uparrow$ & $\uparrow<5 \mathrm{mg} / \mathrm{dl}$ & $\uparrow<6 \mathrm{mg} / \mathrm{dl}$ & $\uparrow<5 \mathrm{mg} / \mathrm{dl}$ & $\uparrow \uparrow$ \\
\hline S. Bil (D) & $\uparrow \uparrow$ & & & & \\
\hline AST & $\uparrow \uparrow$ & Mild $\uparrow$ & $10-20$ fold $\uparrow \uparrow$ & $\uparrow<500$ & $\uparrow 200-700$ & $\uparrow \uparrow$ \\
\hline ALT & $\uparrow \uparrow$ & Mild $\uparrow$ & $10-20$ fold $\uparrow \uparrow$ & $\uparrow<500$ & $\uparrow 200-700$ & $\uparrow \uparrow$ \\
\hline GGT & $\uparrow$ & & & $\uparrow \uparrow$ & & \\
\hline ALP & $\uparrow \uparrow$ & & $\uparrow \uparrow$ & $\uparrow \uparrow$ & & \\
\hline
\end{tabular}




\begin{tabular}{|c|c|c|c|c|c|c|}
\hline LDH & $\mathrm{N} / \downarrow$ & & & & $\uparrow>600$ & \\
\hline Ammonia & $\uparrow$ & & & & $\mathrm{N}$ & $\uparrow$ \\
\hline Glucose & $\downarrow \downarrow$ & $\mathrm{N}$ & $\mathrm{N}$ & $\mathrm{N}$ & $\mathrm{N}$ & $\mathrm{N}$ \\
\hline TG & $\downarrow$ & & & & & \\
\hline $\mathrm{Hb}$ & $\mathrm{N}$ & & & & & \\
\hline Hct & $\mathrm{N}$ & & & & & \\
\hline TLC & $\uparrow$ & & & & $\mathrm{N}$ & $+/-$ \\
\hline Plt. & $\mathrm{N} / \downarrow$ & & & $\mathrm{N}$ & $\downarrow<100,000$ & $\mathrm{~N}$ \\
\hline INR & $\uparrow \uparrow$ & & & $\mathrm{N}$ & $\mathrm{N}$ & $\uparrow$ \\
\hline PTTK & $\uparrow$ & & & $\mathrm{N}$ & $\begin{array}{l}\mathrm{N} / \text { deranged } \\
\text { in late }\end{array}$ & \\
\hline Fibrinogen & $\downarrow \downarrow$ & & & & $\mathrm{N}$ & $\mathrm{N} / \downarrow$ \\
\hline Antithrombin III & $\downarrow \downarrow$ & & & & & \\
\hline BUN & $\uparrow$ & & & & & \\
\hline Uric acid & $\uparrow \uparrow$ & $\mathrm{N}$ & $+/-$ & $\mathrm{N}$ & $\uparrow$ & $\mathrm{N}$ \\
\hline Creatinine & $\uparrow \uparrow$ & & & & & \\
\hline \multirow[t]{3}{*}{ Others } & & & Proteinuria & $\begin{array}{l}\uparrow \text { Bile acids > } \\
10 \mu \mathrm{mol} / \mathrm{L}\end{array}$ & & $\begin{array}{l}\text { Viral } \\
\text { markers } \\
\text { positive }\end{array}$ \\
\hline & & & & $\begin{array}{l}\text { S. cholesterol } \uparrow \mathrm{x} \\
2-4\end{array}$ & & \\
\hline & & & & $\begin{array}{l}\uparrow \mathrm{GST}(\alpha \\
\text { glutathione-S- } \\
\text { transferase } \alpha \text { ) }\end{array}$ & & \\
\hline
\end{tabular}

Table 3: A summary of maternal and fetal complications and their management in different pregnancy related liver disorders.

\begin{tabular}{|c|c|c|c|}
\hline & Maternal complications & Fetal complications & Management of choice \\
\hline $\begin{array}{l}\text { Hyperem } \\
\text { esis }\end{array}$ & $\begin{array}{l}\text { fluid and electrolyte } \\
\text { imbalance } \\
\text { nutritional deficiencies } \\
\text { Ketoacidosis, } \\
\text { liver involvement in 50- } \\
60 \% \text { cases }^{4}\end{array}$ & $\begin{array}{l}\text { Increased incidence of un- } \\
\text { descended testes, ,hip } \\
\text { dysplasia, down syndrome } \\
\text { lower birth weights } \\
\text { sometimes show no } \\
\text { difference }\end{array}$ & $\begin{array}{l}\text { Supportive care } \\
\text { _small frequent meals } \\
\text { _Thiamine and folate supplements } \\
\text { _antiemetic therapy [metoclopramide, } \\
\text { ondansetron, steroids] } \\
\text { _iv fluids } \\
\text { _severe cases - TPN }\end{array}$ \\
\hline $\begin{array}{l}\text { Preeclam } \\
\text { psia or } \\
\text { eclampsi } \\
\text { a }\end{array}$ & $\begin{array}{l}\text { Maternal mortality-15- } \\
20 \% \text { in developing } \\
\text { countries. Maternal renal } \\
\text { failure, pulmonary edema, } \\
\text { CVA (hypertensive crisis), } \\
\text { hepatic rupture }\end{array}$ & $\begin{array}{l}\text { Fetal mortality } 1-2 \% \text {. } \\
\text { Placental abruption, preterm } \\
\text { delivery, fetal growth } \\
\text { restriction }\end{array}$ & $\begin{array}{l}\text { Timely delivery of fetus and placenta, } \\
\text { Expectant management may be done } \\
\text { in preterm }(<36 \mathrm{wks}) \text { with BP control } \\
\text { with } \leq 20 \text { with no s/s of impending } \\
\text { eclampsia }\end{array}$ \\
\hline
\end{tabular}




\begin{tabular}{|c|c|c|c|}
\hline HELLP & $\begin{array}{l}\text { DIC, pulmonary edema, } \\
\text { placental abruption, retinal } \\
\text { detachment, maternal } \\
\text { mortality-1\%-3\% } \\
\text { seizures, ARF, ARDS, } \\
\text { stroke, liver failure, } \\
\text { hepatic infarction/rupture }\end{array}$ & $\begin{array}{l}\text { Abruption, prematurity } \\
\text {,asphyxia, perinatal } \\
\text { mortality } 7-22 \% \text { even upto } \\
35 \%^{7}\end{array}$ & $\begin{array}{l}\text { Prompt delivery } \\
>34 \text { wks-induce } \\
\text { 24-34 wks-corticosteroids with } \\
\text { delivery after } 48 \text { hrs. }\end{array}$ \\
\hline AFLP & $\begin{array}{l}\text { ARF, encephalopathy, } \\
\text { ascites, sepsis, wound } \\
\text { seroma, pancreatitis } \\
\text { MMR-18\% }{ }^{9,10} \text { recurrence } \\
\text { possible }\end{array}$ & $\begin{array}{l}\text { Asphyxia, prematurity, } \\
\text { IUGR, LCHAD deficiency } \\
\& \mathrm{c} / \mathrm{c} \text {. Fetal mortality rate } \\
23 \%(13-18 \%)^{7,9,10} \text { increased } \\
\text { risk of cardiomyopathy, } \\
\text { neuropathy, myopathy, } \\
\text { nonketotic hypoglycemia, } \\
\text { hepatic failure and death } \\
\text { associated with fatty acid } \\
\text { oxidation deposits in } \\
\text { newborns }\end{array}$ & $\begin{array}{l}\text { Prompt delivery } \\
\text { Liver transplant, if diagnosis is } \\
\text { fulminant hepatic failure }\end{array}$ \\
\hline ICP & $\begin{array}{l}\text { Predisposed to cholestasis } \\
\text { in subsequent pregnancies }\end{array}$ & $\begin{array}{l}\text { Chronic placental } \\
\text { insufficiency, preterm } \\
\text { labour, fetal distress, IUD }{ }^{11} \text {, } \\
\text { fetal mortality } 3.5 \%\end{array}$ & $\begin{array}{l}\text { Ursodeoxycholic acid } \\
\text { Beta cholestyramine and s. adenosy }{ }^{11} \\
\text { methionine } \\
\text { Vit K + non fat soluble vitamins }\end{array}$ \\
\hline
\end{tabular}

In conclusion, a high index of suspicion along with judicious use of laboratory investigations can help us reach the diagnosis of acute fatty liver of pregnancy early, so that we are able to reduce both the maternal and perinatal morbidity and mortality.

\section{Funding: No funding sources}

Competing interests: There are no competing interests to declare

Ethical approval: Not required

\section{REFERENCES}

1. Sheehan HL. The pathology of acute yellow atrophy and delayed chloroform poisoning. J Obstet Gynaecol Br Emp 1940;47:49-62.

2. Watson WJ, Seeds JW. Acute fatty liver of pregnancy. Obstet Gynecol Surv 1990;45:585-91.

3. Varner M, Rinderknecht NK. Acute fatty metamorphosis of pregnancy. A maternal mortality and literature review. J Reprod Med 1980;24:177-80.

4. Kallen B. Hyperemesis during pregnancy and delivery outcome: a registry study. Eur J Obstet Gynecol Reprod Biol 1987;26:291-302.

5. Fairweather DV. Nausea and vomiting in pregnancy. Am J Obstet Gynecol 1968;102:135-75.

6. Sibai BM, Ramadan MK, Usta I, Salama M, Mercer BM, Friedman SA. Maternal morbidity and mortality in 442 pregnancies with hemolysis, elevated liver enzymes and low platelets (HELLP syndrome). Am J Obstet Gynecol 1993;169:1000-6.

7. Ko HH, Yoshida E. Acute fatty liver of pregnancy. Can J Gastroenterol 2006;20:25-30.

8. Lee NM, Brady CW. Liver disease in pregnancy. World J Gastroenterol 2009;15:897-906.

9. Knox TA, Olans LB. Liver disease in pregnancy. N Engl J Med 1996;335:569-76.

10. Castro MA, Fassett MJ, Reynolds TB, Shaw KJ, Goodwin TM. Reversible peripartum liver failure: a new perspective on the diagnosis, treatment, and cause of acute fatty liver of pregnancy, based on 28 consecutive cases. Am J Obstet Gynecol 1999;181:389-95.

11. Tan LK. Obstetric cholestasis: current opinions and management. Ann Acad Med Singapore 2003;32:294-8.

12. Airede LR, Nnadi DC. The use of the condomcatheter for the treatment of postpartum haemorrhage - the Sokoto experience. Trop Doct 2008;38:84-6.

13. Georgiou C. Balloon tamponade in the management of postpartum haemorrhage: a review. BJOG 2009;116:748-57.

DOI: $10.5455 / 2320-1770.1 j \mathrm{rcog} 20130221$

Cite this article as: Gami N, Singhal S, Puri M, Dhakad A. An approach to diagnosis and management of acute fatty liver of pregnancy. Int J Reprod Contracept Obstet Gynecol 2013;2:104-8. 